Hikmah: Journal of Islamic Studies, 16 (1), 2020, 100-120

http://journal.uinjkt.ac.id/index.php/HIKMAH

DOI: 10.47466/hikmah.v16i1.163 | P-ISSN. 2088-2629, E-ISSN. 2581-0146

\title{
IHSAN KEPADA KEDUA ORANG TUA: TINJAUAN TAFSIR SOSIAL KONTEMPORER
}

\author{
Muhammad Shodiq \\ STFI Sadra Jakarta, Indonesia \\ shodiqm313@gmail.com
}

\begin{abstract}
This study aims to reveal the interpretation of the Koran about doing good (ihsan) to parents which is explicitly mentioned 13 (thirteen) times, and which is mentioned 7 (seven) times directly after Allah swt invites and calls on people to tauhid and thanksgiving. to him. In social practice, how a person has good character to both parents is revealed in this study with Tafsir al-Amthal fi Tafsir Kitabillah al-Munzal by Makarim Syairazi as the primary source. This Interpretasion is a contemporary social interpretation. Meanwhile, the secondary data in this study are other authoritative and relevant social interpretation works. The findings of this research are that the meaning of ihsan applies to both parents in the Koran is in the form of monotheism that must be put forward to accompany the worship of both parents. Ihsan is absolute covering all goodness, including the category whether the religious status of both parents is Muslim or infidel. be civilized when both parents are weak, old and old, who desperately need protection and affection from their children. Be gentle and respectful when communicating with him. Be tawadhu 'and pray for them when they are still alive or not. Always ask Allah for an easy way to serve both parents.
\end{abstract}

Keywords: Ihsan; parents; contemporary social interpretation

\begin{abstract}
Abstrak
Penelitian ini bertujuan untuk mengungkap penafsiran Al-Quran tentang berbuat baik (ihsan) kepada orang tua yang secara tersurat disebutkan sebanyak 13 (tiga belas) kali, dan yang 7 (tujuh) kali disebut langsung setelah Allah swt mengajak dan menyerukan umat kepada tauhid dan sukur kepada-Nya. Dalam praktik sosial, bagaimana seseorang berakhlaq baik kepada kedua orang tua diungkap dalam penelitian ini dengan Tafsir al-Amthal fi Tafsir Kitabillah al-Munzal karya Makarim Syairazi sebagai sumber primer. Tafsir Al-Amthal merupakan tafsir yang bercorak sosial kontemporer. Sedang data sekunder dalam penelitian ini adalah karya tafsir sosial lainnya yang otoritatif dan relevan dengan kajian ini. Temuan penelitin ini adalah bahwa makna berlaku ihsan kepada kedua orang tua dalam Al-Quran adalah berupa tauhid yang harus dikedapankan yang mengiringi kebaktian terhadap kedua orang tua. Ihsan bersifat mutlak meliputi semua kebaikan termasuk kategori apakah status agama kedua orang tua muslim ataupun kafir. bersikap beradab ketika kedua orang tua dalam masa lemah, renta dan tua yang sangat membutuhkan perlindungan dan kasih sayang dari anaknya. Bersuara lembut dan hormat ketika berkomunikasi dengannya. Bersikap tawadhu' dan mendoakan mereka ketika masih hidup maupun telah tiada. Selalu memohon kepada Allah untuk di anugerahi jalan mudah untuk berkhidmat kepada kedua orang tua.
\end{abstract}

Kata Kunci: Ihsan; orang tua; tafsir sosial kontemporer 


\section{PENDAHULUAN}

Pekembangan ilmu pengetahuan dan teknologi disamping meberikan dampak positif bagi generasi muda, juga memberikan dampak negatifnya. Banyak generasi muda yang memiliki akhlak kurang baik karena pengaruh prilaku dan gadget yang memicu ketegangan pikiran dan menjadikan nalar tidak terkontrol. Banyak orang yang terlalu fokus dan asyik dengan tingkah lakunya, tanpa memperhatikan perasaan dan situasi di sekelilingnya yang terdekat. Banyak orang mengadakan petemuan secara fiksik, namun tangan dan mata justru tertuju pada gawainya. Para generasi muda yang dianggap melek teknologi kini sudah tidak lagi memiliki perhatian lagi kepada orang tua dan keluarga. Bahkan hal ini pada akhirnya merembet pada penurunan akhlak mereka terhadap orang tua. Para anak muda sudah tidak lagi mendengarkan nasihat orang tua bahkan berkata kasar dan tidak sopan kepada orang tua.

Dalam bahasa Indonesia banyak sekali kata yang dapat mewakili makna perilaku di antaranya adalah tata krama, adab, akhlak, moral, sikap, kelakuan, aksi, dan lain sebagainya. Oleh karena itu kata etika memiliki banyak sinonim. Meski demikian, terma akhlak dalam kaitan pengkajian lebih mampu mewakili makna ayat-ayat Al-Quran yang membahas etika dan moral dalam berprilaku sosial. Kata akhlak banyak menjadi tema pembahasan seperti Al-Akhlaq al-Quraniyyah, Al-Akhlaq fi al-Quran, al-Aqidah wa alAkhlaq, bahkan secara tegas kata Akhlak merupakan salah satu mata pelajaran etika dan moral yang resmi terdapat dalam kurikulum pendidikan Islam di Indonesia.

Kata etika merupakan serapan dari istilah bahasa Yunani kuno yaitu "ethikos' berarti 'timbul dari kebiasaan. Bentuk tunggal kata 'etika' yaitu ethos, sedangkan bentuk jamaknya yaitu ta etha. Ethos mempunyai banyak arti yaitu: tempat tinggal, yang biasa, padang rumput, kandang, kebiasaan/adat, akhlak, watak, perasaan, sikap, cara berfikir. ${ }^{1}$ Sedangkan arti ta etha yaitu adat kebiasaan. Arti kata bentuk jamak inilah yang melatarbelakangi istilah etika. dari secara etimologis (asal usul kata) etika mempunyai arti yaitu ilmu tentang apa yang biasa dilakukan atau ilmu tentang adat kebiasaan. Sedangkan akhlak adalah istilah bahasa Indonesia yang diserap langsung dari bahasa Arab yaitu Akhlaq.

Al-Qur'an merupakan ejawantah fitrah manusia, dan Rasulullah merupakan idealisasi dari fitrah manusia seperti yang tertulis dalam hadits yang menyatakan : Kaana khuluquhu Al-Quran,2 "Akhlak Muhammad adalah Al-Quran itu sendiri. Juga ditulis dalam ayat AlQur'an: Wa innaka la'alaa khuluqin 'azhiim. "Dan sesungguhnya kamu (Muhammad) benar-benar berbudi pekerti yang agung” sebagaimana dalam QS. Al-Qalam ayat 4. ${ }^{3} \mathrm{Al}$ -

\footnotetext{
${ }^{1}$ Bertens, Etika, (Jakarta: Gramedia Pustaka Utama, 2000)

${ }^{2}$ Al- Bukhari, Shahih al-Bukhari, (Beirut: Dar al-Fikr, 2000).

${ }^{3}$ Abdullah, Irwan, Sangkan Paran Gender, (Yogyakarta: Pustaka Belajar, 2006), Cet.Ke-3, h. 13.
} 
Quran merupakan peraturan bagi umat sekaligus sebagai way of life yang kekal hingga akhir masa. ${ }^{4}$

Esensi yang terkandung di dalam QS. An-Nissa: 36, QS. Al-Israa': 23-24, QS. AlAnkabuut: 8 dan QS. Al-Ahqaaf: 15, di antaranya: (1) Seorang anak harus bersikap dan berperilaku baik terhadap kedua orang tua dalam ucapan maupun perbuatan. (2) Setiap anak perlu memiliki pengetahuan tentang akhlak anak terhadap orang tua. (3) Pentingnya pendidikan akhlak anak terhadap orang tua terkait tanggung jawab, etika dan sopan santun. Akhlak anak terhadap orang tua yang terdapat dalam Al-Qur'an, menjelaskan bahwa seorang anak hendaknya: (1) Berbuat baik kepada kedua orang tuanya, dalam keadaan bagaimanapun dan tidak boleh sekali-kali membalas dan mengimbangi ketidakbaikan orang tua kepadanya. (2) Memuliakan ibu-bapaknya tanpa mengharapkan apapun sebagai balasannya. (3) Menjalankan kewajiban seorang anak terkait akhlak anak terhadap orang tua dalam mendo'akan kedua orang tua semasa hidupnya atau setelah mereka tiada. (4) Menjauhi larangan Allah SWT yang berkenaan dengan durhaka terhadap orang tua. (5) Menunaikan hak orang tua dan kewajiban terhadap mereka selagi tidak dalam rangka mempersekutukan Allah SWT. ${ }^{5}$ Oleh karena itu perlu diungkap secara mendalam apa saja pesan Al-Quran kepada manusia dalam bersosial dengan manusia yang paling berjasa atas dirinya, yaitu kedua orang tua.

\section{METODE}

Kajian ini merupakan bentuk kajian riset kualitatif dengan pendekatan penafsiran sosial (Tafsir ijtima'i). Tafsir Ijtima'I adalah pemahaman terhadap teks AlQur'an yang terbuka untuk ditarik dalam ruang lingkup problematika sosial, baik dari aspek hukum maupun aspek-aspek yang langsung bersentuhan dengan permasalahan sosial kemasyarakatan yang terjadi pada masa kini dan yang akan datang.

Mengacu pada hal itu, sumber primer kajian ini adalah buku Tafsir al-Amthal $f i$ Tafsir Kitabillah al-Munzal karya Makarim Syairazi. Tafsir Al-Amthal merupakan tafsir yang bercorak sosial kontemporer. Sedang data sekunder dalam penelitian ini adalah karya tafsir sosial lainnya yang otoritatif dan relevan dengan kajian ini. Semua ayat Al-Quran yang menyinggung tentang ihsan kepada orang tua diungkap penafsirannya secara detail dan dianalogikan turunan pesan dan sikap yang wajib dilakukan secara konkret kepada kedua orang tua.

${ }^{4}$ Fatkhul Mannan Jazuli, “Konsep Pendidikan Akhlak Anak terhadap Orang Tua Dalam Al-Qur'an Surat Al Isra 23-25, Skripsi, IAIN Salatiga, 2015.

${ }^{5}$ Angga Hermawan, Adliyah Adliyah, M Imam Pamungkas, “Akhlak Anak terhadap Orang Tua Berdasarkan Al-Qur'an (Analisis Pendidikan terhadap QS. An-nissa: 36, QS. Al-Israa’: 23-24, QS. Al-Ankabuut: 8 dan QS. AlAhqaaf: 15), Proceeding Pendidikan Agama Islam, Vol 3, No 2, Agustus, 2017), 113-119, h. 113.

${ }^{6}$ Abdul Karim, “Reformulasi Tafsir Ijtima’i dalam Menjawab Problematika Sosial”, Hermeneutik, Vol. 9, No.2, Desember 2015, 401-422, h. 404. 


\section{HASIL DAN PEMBAHASAN}

\section{Akhlak sebagai Bentuk Sikap Ihsan kepada Kedua Orang Tua}

Kata akhlak dalam kamus besar bahasa Indonesia berarti 'budi pekerti dan kelakuan'. Kata akhlak juga merupakan serapan kata dari bahasa Arab (أخلاق), kata jamak dari kata khuluq (خلق) yang bermakna 'kelakuan sifat psikis atau suatu perangai kejiwaan yang mendasar pada diri manusia’.

Perangai ini dapat memotivasi manusia untuk melakukan suatu tindakan atau perbuatan tanpa memerlukan proses nalar berfikir maupun pertimbangan terlebih dahulu, seperti jiwa kedermawanan yang terdapat pada manusia sebagai perangai yang mendasar, ketika dia berderma tanpa ragu dan sepontan dia akan melakukannya, meskipun perangai ini dihasilkan dari kebiasaan yang sering diulang-ulang atau mungkin sudah menjadi karakter bawaannya secara biologis ataupun karena faktor genetik dan karena faktor-faktor lain yang membentuknya. Konsep demikian ini tidak ada kaitannya dengan arti bahasanya secara khusus namun dalam pemahaman kata ini dapat ditujukan pada dua makna yang berbeda antara akhlaq yang terpuji dan yang tercela.

Menurut istilah, kata Akhlak digunakan dalam tiga pengertian. Pengertian pertama, digunakan sama sebagaimana arti bahasanya yaitu perangai kejiwaan (psikologis). Pengertian kedua, terkadang digunakan pada sifat perbuatan manusia, meskipun perangai jiwa ini masih tidak terdapat pada dirinya yang masih membutuhkan proses nalar untuk menumbuhkannya, namun tetap keadaan perbuatannya dapat disebut dengan kategori akhlaq terpuji ataupun akhlak yang tercela.

Perbedaan dua istilah tersebut adalah pada istilah pertama dimaksudkan untuk makna perangai kejiwaan (psikologis) yang mendasar dalam diri manusia, meskipun keadaanya tidak fundamental namun ia masih dapat disifati dengan sifat terpuji maupun tercela. Pada istilah kedua kata Akhlaq mencakup sifat-sifat psikologis yang menjadi sebab munculnya sifat terpuji atau sifat tercela meskipun kedaannya fundamental maupun tidak fundamental dan terpaksa.

Pengetian terakhir yaitu ketiga adalah istilah akhlak terkadang hanya digunakan untuk yang terpuji seperti pengorbanan, karena pengorbanan adalah akhlak yang baik maka sifat itu termasuk akhlak. Sedangkan penganiayaan adalah bukan akhlak karena sifat itu termasuk jahat. Pada istilah yang ketiga ini, tidak ada perbedaan antara keadaan

\footnotetext{
${ }^{7}$ Depdikbud, Kamus Besar Bahasa Indonesia, (Jakarta: Balai Pustaka, 2003).

${ }^{8}$ Majma' al-Lughah al-'Arabiyyah, al-Mu'jam al-Wasith, (Kairo: Maktabah al-Syuruq al-Dualiyyah, 1999). Ibnu Manzhur, Lisan al-Arab, Kairo : Dar al-Hadith, 1995). Ibnu Fariz, Maqayis al-Lughah, (Kairo: Dar al-Hadith, 2008).
} 
perbuatan maupun karakter, akhlak bermakna yang terpuji pada keadaan dan karakter manusia ${ }^{9}$.

Dari uraian makna etimologi kata akhlak dan pengertian istilahnya yang digunakan dalam konsep agama, dapat disimpulkan bahwa akhlak merupakan salah satu unsur fundamental selain aqidah (keyakinan) dan syariah yang harus dimiliki oleh seorang religius secara kompreshensif untuk menata hidupnya baik untuk kebutuhan hidup individual dan sosial berkaitan dengan antar sesama manusia maupun dengan Tuhannya. Salah satu dari ruang lingkup kehidupan ini adalah bagaimana berakhlak dan berlaku etis terhadap kedua orang tua.

\section{Menghormati dan Berbuat Baik kepada Bapak dan Ibu}

Menghormati dan berbuat baik kepada kedua orang tua (Ibu dan bapak) merupakan salah satu dari prinsip-prinsip yang penting dalam akhlak dan etika sebagaimana yang telah banyak ditegaskan di dalam ajaran-ajaran al-Quran dan para manusia suci as, untuk menjelaskan tema penting ini harus dikaji berbagai aspek.

Berbuat baik dan menghormati kepada kedua orang tua memiliki cakupan arti yang begitu luas, harus menjauhi apapun bentuk dan macam yang dapat menyebabkan sakit hati dan ketidakrelaan mereka, begitu juga sebaliknya tentang apapun yang membahagiakan dan merelakan keduanya secara beradab dan layak harus tunduk dan pasrah melakukannya. Al-Quran dengan tegas menyatakan dalam surah al-Isra' ayat 23:

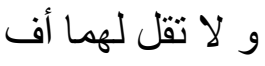

Artinya:

"Janganlah kamu mengatakan kepada kedua orang tua perkataan "ah”...”.

Maksudnya adalah supaya menghindari dari sebesar sampai sekecil apapun ucapan dan perlakuan yang membuat mereka tidak meridhainya, walapun hanya dengan kata "ah" (أف) sebagai ungkapan yang paling sederhana dari ungkapan yang tidak beradab atau sebagai ekspresif dari hal yang tidak disukai.

Jakfar Shodiq berkata:

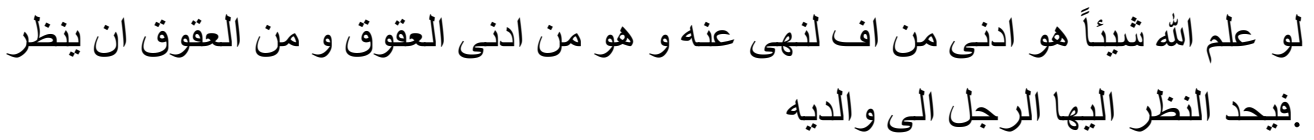

Artinya:

“Andaikan disisi Allah terdapat hal yang lebih rendah dari sekedar bekata "ah” (أف) kepada kedua orang tua pasti Dia akan melarangnya, namun inilah bentuk paling terkecil

${ }^{9}$ Muhammad Taqi Misbah, Falsafehye Akhlaq, (Tehran: Ettela'at, 1376), cet. 6, hal 9-10. 
dari sikap tidak menghormati mereka yaitu seorang memandang keduanya lalu seketika memalingkan tatapannya". ${ }^{10}$

Berkata "ah" sebagai hal yang tidak diperbolehkan untuk diungkapkan kepada kedua orang tua, dapat difahami dari riwayat diatas bahwa betapa ruang lingkup arti penghormatan dan ihsan kepada mereka begitu luas. Menghormati dan berbuat baik (ihsan) kepada kedua orang tua prespektif Al-Quran telah disebut sebanyak 13 (tiga belas) kali, dan yang 7 (tujuh) kali disebut langsung setelah Allah swt mengajak dan menyerukan umat kepada tauhid dan sukur kepada-Nya, ini menunjukkan betapa luar biasa dan mulianya menghormati dan berbuat baik (ihsan) terhadap kedua orang tua.

Allah berfirman dalam surah al-Baqarah ayat 83 :

$$
\text { و إذ أخذنا ميثاق بنى إسر ائيل ألا تعبدون إلا الله و بالو الدين إحساناً ذ ذي القربى }
$$

Artinya:

"Dan (ingatlah), ketika Kami mengambil janji dari Bani Israil (yaitu): Janganlah kamu menyembah selain Allah, dan berbuat kebaikanlah kepada ibu bapak....

Ayat tersebut berbicara tentang komitmen yang telah diambil dari bani Isra'il, namun mereka menyalahi komitmen ini sehingga mendapatkan cibiran yang negatif dari Allah swt. Beberapa poin komitmen yang prinsip adalah tauhid kemudian berbuat baik kepada kedua orang tua dan poin-poin berikutnya, demikian ini merupakan nilai universal bagi semua bangsa tidak terbatas bagi Bani Isra'il. Konsep hidup umat manusia yang disebut di dalam ayat tersebut berkenaan dengan Bani Israil sesungguhnya merupakan rangkaian konsepkonsep universal untuk semua bangsa dunia. Ditegaskan bahwa faktor-faktor penentu untuk menghidupkan dan menjayakan atau yang dapat menjadikannya factor yang dapat merusak dan menghancurkan mereka adalah bergantung pada komitmennya. ${ }^{11}$

Allah berfirman dalam surah al-Nisa ayat 6:

$$
\text { و اعبدو الله و لاتشركو ا به شيئًاً بالو الدين إحسانا! }
$$

Artinya:

"Sembahlah Allah dan janganlah kamu mempersekutukan-Nya dengan sesuatupun. Dan berbuat baiklah kepada dua orang Ibu-Bapak."

Ayat tersebut di atas menjelaskan beberapa masalah tentang hak-hak islami yaitu hak Allah dan hak hamba-hamba-Nya termasuk tata cara interaksi dengan masyarakat. Pertama: umat diajak untuk menyembah Allah swt dan meninggalkan penyekutuan-Nya yang merupakan akar utama bagi seluruh konsep agama Islam, tauhid dan monotheisme

\footnotetext{
jilid 12, h. 97.

${ }^{10}$ Makarim Syirazi, Tafsir al-Amthal fi Tafsir Kitabillah al-Munzal, (Tehran: Dar al-Kutub al-Islamiyah, 1385),

${ }^{11}$ Makarim Syirazi, Tafsir al-Amthal fi Tafsir Kitabillah al-Munzal, jilid 1, h. 382-387.
} 
dapat mensucikan jiwa dan mejernihkan niat, serta menguatkan tekad untuk dapat melaksanakan program-progaram kehidupan yang mulia. Ayat tersebut menjelaskan serangkaian tentang hak-hak islami yang didahuli oleh hak Tuhan dengan ungkapan:

$$
\text { و اعبدو الله و لا تشركو ا به شيئًا }
$$

Artinya:

"Sembahlah Allah dan janganlah kamu mempersekutukan-Nya dengan sesuatu apapun”

Kedua, hak ayah dan Ibu disebutkan yaitu pada ungkapan و و بالو الدين إحسانا Tema tentang kedua orang tua di dalam Al-Quran menjadi perhatian yang sangat serius, menghormati dan berihsan kepada mereka disandingkan setelah ajakan tauhid, demikian ini menunjukkan adanya hubungan erat sebagai fenomena hakikat wujud, karena nikmat yang paling besar adalah nikmat wujud dan kehidupam yang telah Allah ciptakan, dan kemudian tahapan berikutnya adalah berhubungan dengan adanya kedua orang tua yang menjadi perantara terciptanya wujud manusia. Oleh karena itu bahwa sesungguhnya meninggalkan hak kedua orang tua sama halnya dengan kategori sebagai penyukutuan terhadap Allah swt. ${ }^{12}$

Allah berfirman dalam surah Al-An'am ayat 151:

$$
\text { قل تعالو ا اتل ما حرم ربكم عليكم ألا تشركو ا به شيئًا و بالو الدين إحساناً }
$$

Artinya:

"Katakanlah: "Marilah kubacakan apa yang diharamkan atas kamu oleh Tuhanmu yaitu: janganlah kamu mempersekutukan sesuatu dengan Dia, berbuat baiklah terhadap kedua orang Ibu Bapak..."

Di dalam ayat tersebut di atas dijelaskan tentang hal yang dilarang oleh Allah swt, yang menarik adalah setelah kesyirikan atas Allah swt diurutan berikutnya adalah berihsan kepada kedua orang tua diketengahkan: "Kemarilah, akan aku sampaikan apa yang dilarang oleh Tuhan atas kalian yaitu janganlah menyekutukan-Nya dan berikutnya adalah terhadap kedua orang tua hendaklah kalian berbuat ihsan..." .

Allah memulai menjelaskan hal yang terlarang dimulai dengan syirik menunjukkan bahwa menurut rumusan Al-Quran syirik merupakan biang utama dari semua kerusakan sosial, kemudian disebut setelahnya berbuat baik kepada kedua orang tua (bapak dan Ibu), bahkan ini sebelum peraturan-peraturan penting yang lain seperti larangan membunuh dan pelaksanaan prinsip-prinsip keadilan, ini menunjukkan betapa pentingnya hak kedua orang tua di dalam konsep agama Islam, demikian ini jelas karena ayat tersebut tidak

\footnotetext{
${ }^{12}$ Makarim Syirazi, Tafsir al-Amthal fi Tafsir Kitabillah al-Munzal, jilid 3, h. 479.
} 
menyebutkan kalimat larangan perbuatan terhadap orang tua seperti larangan-larangan yang disebut justru malah disebutkan Ihsan dan berbuat baik kepada mereka. ${ }^{13}$ Maksudnya adalah disamping dilarang berbuat hal yang menyakiti mereka tetapi juga penting untuk berbuat baik kepada mereka.

Allah juga berfirman dalam surah al-Isra' ayat 23:

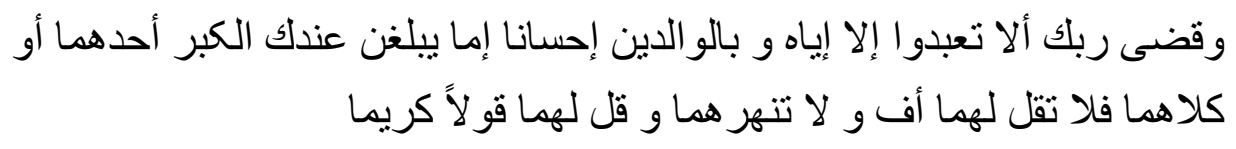

Artinnya:

"Dan Tuhanmu telah memerintahkan supaya kamu jangan menyembah selain Dia dan hendaklah kamu berbuat baik pada ibu bapakmu dengan sebaik-baiknya. Jika salah seorang di antara keduanya atau kedua-duanya sampai berumur lanjut dalam pemeliharaanmu, maka sekali-kali janganlah kamu mengatakan kepada keduanya perkataan "ah" dan janganlah kamu membentak mereka dan ucapkanlah kepada mereka perkataan yang mulia”.

Selain itu, dalam surah al-Isra' ayat 24 juga disebutkan:

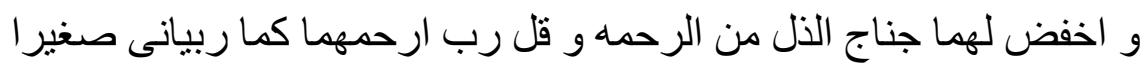

Artinya:

"Dan rendahkanlah dirimu terhadap mereka berdua dengan penuh kesayangan dan ucapkanlah: "Wahai Tuhanku, kasihilah mereka keduanya, sebagaimana mereka berdua telah mendidik aku waktu kecil”.

Pada ayat قضى bermakna lebih di atas perintah dan lebih pasti, demikian ini menunjukkan bahwa tauhid adalah sebagai prinsip yang paling dominan dan berikutnya berbuat baik terhadap Ibu dan bapak merupakan hal yang prinsip juga didalam aturan-aturan bermasarakat didalam Islam.

\section{Tauhid dan Berbuat Baik terhadap Kedua Orang Tua}

Prinsip tauhid merupakan salah satu dari prinsip yang paling fundamental dalam ajaran-ajaran para Nabi as, Allah swt telah memerintahkan didalam ayat diatas untuk meyembah hanya kepa-Nya dan hendaknya berbakti terhadap kedua orang tua sebagaimana ditegaskan dalam surah al-Isra' ayat 23:

\footnotetext{
${ }^{13}$ Makarim Syirazi, Tafsir al-Amthal fi Tafsir Kitabillah al-Munzal, jilid 6, h. 43-47.
} 


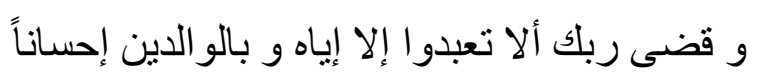

Artinya:

"Dan Tuhanmu telah memerintahkan supaya kamu jangan menyembah selain Dia dan hendaklah kamu berbuat baik pada ibu bapakmu dengan sebaik-baiknya.”

Ihsan bersifat mutlak meliputi semua kebaikan termasuk kategori apakah status agama kedua orang tua muslim ataupun kafir. Diperlukan kejelian dan detail dalam memandang bagaimana menghormati kedua orang tua, sebagaimana yang telah tersurat di dalam dua ayat tersebut di atas.

Ada beberapa hal penting yang diungkap dari ayat di atas. Pertama, ayat itu mengingatkan bagaimana harus bersikap beradab ketika kedua orang tua dalam masa lemah, renta dan tua yang sangat membutuhkan perlindungan dan kasih sayang dari anaknya, sekecil apapun jangan sampai ada ucapan yang malah membebeni mereka. Kedua: mengingatkan pada tanggung jawab yang lebih berat ketika kedua orang tua berada pada masa paling lemah bahkan secara mandiri tidak dapat mengurusi dirinya, yang merupakan ujian berat, apakah demikian ini dianggap sebagai rahmat ataukah beban dan bencana, apakah sabar menanggungnya ataukah malah mengharapkan untuk secepat mungkin menutup usianya. Ketiga: Allah swt dalam kondisi bagaimanapun orang tua melarang walau hanya sekedar mengucapkan "ah" kepadanya sebagai ekspresi tidak senang kepadanya, jangan mengangkat suara dihadapannya, hendaknya dengan suara dan bahasa lembut dan hormat ketika berkomunikasi dengannya. Keempat, Al-Quran telah memerintahkan dihadapan mereka untuk bersikap tawadhu' sebagai bukti cinta dan bukan karena maksud yang selainnya. Kelima: tidak melupakan kedua orang tua dalam keadaan hidup atau matinya untuk mendoakan mereka, dan memohonkan ampunan Allah bagi mereka.

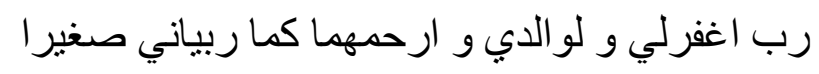

Artinya:

"Ya Allah (Tuhanku) ampunilah aku dan kedua orang tuaku, sayangilah keduanya sebagaimana keduanya telah mendidikku dimasa kecilku."

Keenam, jangan melupakan diri dengan kesombongan dihadapan kedua orang tua yang lemah karena suatu hari akan datang masa yang sama bagi sesorang yang membutuhkan hal yang sama berupa perhatian dan kasih sayang, ini adalah balasan budi yang tak akan bisa tertunaikan meskipun sulit untuk dilakukan kecuali dengan taufiq dan 
jalan mudah dari Allah, karena itu memohonlah kepada Allah untuk di anugerahi jalan mudah demi menunaikan khidmat kepada kedua orang tua. ${ }^{14}$

Wasiat Allah swt kepada manusia swt atas Bapak dan Ibu

Allah Swt. berfirman dalam surah Al-Ahqaf ayat 15 mengenai berbuat baik kepada kedua orang tua:

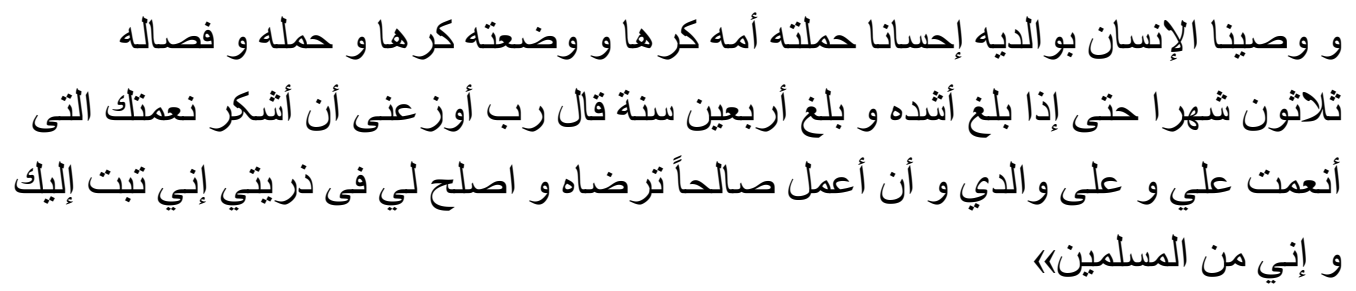

Artinya:

"Kami perintahkan kepada manusia supaya berbuat baik kepada dua orang ibu bapaknya, ibunya mengandungnya dengan susah payah, dan melahirkannya dengan susah payah (pula). Mengandungnya sampai menyapihnya adalah tiga puluh bulan, sehingga apabila dia telah dewasa dan umurnya sampai empat puluh tahun ia berdoa: "Ya Tuhanku, tunjukilah aku untuk mensyukuri nikmat Engkau yang telah Engkau berikan kepadaku dan kepada ibu bapakku dan supaya aku dapat berbuat amal yang saleh yang Engkau ridhai; berilah kebaikan kepadaku dengan (memberi kebaikan) kepada anak cucuku. Sesungguhnya aku bertaubat kepada Engkau dan sesungguhnya aku termasuk orang-orang yang berserah diri".

Sebelum ayat ini Allah swt berfirman dan menjelaskan tentang keadaan orang-orang mukmin yang teguh dan komitmen dengan keimanannya, berani dan tak gentar terhadap apapun, mereka adalah para penghuni surga, berikutnya menjelaskan tentang kebaikan terhadap kedua orang tua dan berbuat terima kasih atas budi mereka sebagai mukaddimah untuk bersukur dan berterima kasih kepada Allah swt, dikatakan.

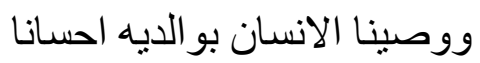

Wasiat bermakna pesan yang universal, makna dan pengertiannya tidak terbatas pada jaman tertentu, para mufassir sebagian mereka menafsirkan dengan arti perintah, setelah menegaskan untuk berbuat baik kepada kedua orang tua dijelaskan tentang hak seorang Ibu yang dengan susah payah mengandung anak, dan juga melahirkannya dengan susah payah, sampai menyapihnya dalam tiga puluh bulan,

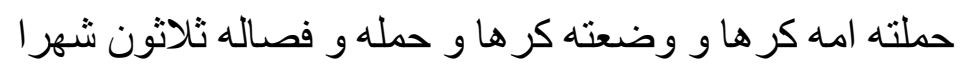

\footnotetext{
${ }^{14}$ Makarim Syirazi, Tafsir al-Amthal fi Tafsir Kitabillah al-Munzal, jilid 6, h. 90-91.
} 
Seorang ibu sepanjang masa itu sungguh ia menampakkan pengorbanannya yang paling berat dan menampilkan dirinya dengan menanggalkan ego pribadi untuk melindungi dan membesarkan anaknya, mendidik dan membinanya dengan segalanya tanpa pamrih apapun.

Sejak positif kehamilan seorang ibu hari demi hari dirundung kecemasan dan kekhawatiran, semakin janin berkembang semakin kebutuhan nutrisi dan gizi bertambah darinya, betapa ini berpengaruh pada kekuatan tulang dan urat sarafnya sehingga tidak dapat diingkari waktu tidur, istirahat dan ketenangan harus dikorbankan demi janinnya bahkan kadang sampai dalam kondisi susah untuk dapat bangun duduk, namun karena rasa cinta yang kuat untuk cepat melihat janinnya terlahir di dunia, dapat memandang senyum dan tawanya betapa ini semuanya dapat mengobati dan membuatnya bertahan menanggung beban yang berat.

Paling berat beban saat-saat hidup seorang ibu adalah ketika melahirkan anaknya, ketika saat-saat genting dan kritis ini tiba, banyak ibu-ibu yang telah mengorbankan jiwanya meski anaknya tetap hidup, kalaupun keduanya selamat dari sini dimulai masamasa melindungi secara kontinyu tidak mengenal waktu siang dan malam untuk menjawab kebutuhannya, ketika masih balita meski komunikasi tidak bisa berlangsung secara verbal dan sulit dimengerti ketika anak merasa sakit, lapar dan haus, kedinginan, kepanasan dan keadaan yang lain-lainnya yang hanya dengan tangisan dan jeritan diekspresikan olehnya, namun seorang ibu dengan sepenuhnya tabah dan sabar dan penuh kasih sayang berusaha mengidentifikasi kebutuhannya melebihi seorang dokter spesialis, termasuk bagaimana menjaga kebersihannya yang begitu menyiksanya, balita ketika terserang penyakit betapa seorang ibu berusaha dengan segala daya dan kemampuannya untuk menyelamatkannya.

Al-Quran dalam ayat tersebut hanya menyebutkan kesulitan dan beban seorang Ibu tapi tidak menyebutkan bagaimana kesulitan seorang ayah, bukan berarti tidak peduli terhadap kedudukannya akan tetapi seorang ayah adalah dalam posisi sekutu dalam semua kesulitan dan beban seorang Ibu, meskipun Ibu lebih terbebani sehingga eksklusif disebut tanpa keadaan ayah. Beban ini ditanggung mereka berdua sampai anaknya dewasa dan dapat mandiri dalam usia yang matang 40 tahun.

Sebagaimana dalam lanjutan firman-Nya :

$$
\text { حتى اذا بلغ اشده و بلغ اربعين سنه }
$$

Nashir Makarim Syirazi berpendapat bahwa kedewasaan yang dimaksud didalam ayat ini adalah kedewasaan logika yaitu ketika umur 40 tahun biasanya sesorang matang logikanya, karenanya para Nabi as diangkat dalam usia yang matang ini, tapi dewasa secara 
fisik adalah sebagaimana para ulama berpendapat sebagian dengan masuknya usia baliq atau masuk di usia 18 tahun. $^{15}$

Al-Qur'an setelah menyebutkan bahwa masa paling matang kedewasaan manusia di umur 40 tahun, semestinya ia memohon dari Allah swt tiga hal. (1) Ya Tuhanku, tunjukilah aku untuk mensyukuri nikmat-MU yang telah Engkau berikan kepadaku dan kepada ibu bapakku”.

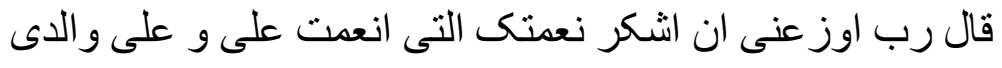

Pada umur kedewasaan yang matang ini seorang monoteis yang beriman mengetahui dan menyadari betapa besar kenikmatan yang telah diberikan kepadanya dari Allah swt begitu juga dari Ayah ibu yang telah dirasakannya, demikian ini karena pada usia ini umumnya sesorang telah menjadi ayah atau seorang ibu yang tentu kini merasakan juga bagaimana jerih payah dan beban kedua orang tua dan perngorbanan yang harus diberikan kepada anaknya sehingga juga termasuk menjadi jalan untuk bisa mensukuri Allah swt. (2) Berikutnya secara khusus bagi dirinya sendiri untuk memohon kepada Allah swt agar dapat beramal sholeh yang diridhai-Nya

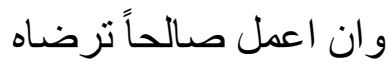

(3) Selanjutnya agar memohon kebaikan kepada anak cucuku (keturunanku) yang berpengaruh kebaikannya kepadaku.

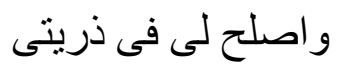

Yang menarik dari permohonan- permohonan diatas adalah pada yang pertama seorang mengikutkan kedua orang tuanya baru kemudia permohonan untuk pribadinya dan selanjutnya melibatkan anak cucu dan keturunannya, demikian ini menunjukkan bahwa seorang yang shaleh dan religius tidak bersikap egois dan tidak memandang penting dirinya sendiri namun juga harus memandang pribadi-pribadi yang selainnya yang memiliki hak atas pribadinya.

Pada akhirnya terdapat dual hal penting yang disebutkan yang masing-masing mengindikasikan adanya program hidup yang mulia secara praktis yaitu pertama taubat kepada Allah swt "انى تبت اليك" sesungguhnya aku pada usia matang ini kembali kepadamu (bertaubat) dan harus menentukan garis jalan hidup dan betapa hina bila tidak kembali di jalan Allah. Yang kedua adalah bahwa sesungguhnya aku tergolong orang-orang yang pasrah diri kepada-Mu “ و انى من المسلمين".

\footnotetext{
${ }^{15}$ Makarim Syirazi, Tafsir al-Amthal fi Tafsir Kitabillah al-Munzal, jilid 21, h. 344
} 


\section{Bentuk Konkret Akhlak Baik kepada Orang Tua}

Ada beberapa bentuk sikap dan perilaku yang mencerminkan akhlak baik kepada orang tua. Di antaranya adalah berkata-kata dengan sopan dan penuh kelembutan, dan jauhi perkataan yang menyakiti hati mereka. Allah berfirman dalam QS. Al-Isra' ayat 23.

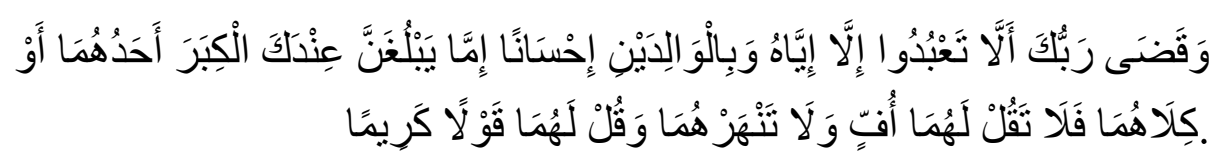

"Dan Tuhanmu telah memerintahkan supaya kamu jangan menyembah selain Dia dan hendaklah kamu berbuat baik pada ibu bapakmu dengan sebaik-baiknya. Jika salah seorang di antara keduanya atau kedua-duanya sampai berumur lanjut dalam pemeliharaanmu, maka sekali-kali janganlah kamu mengatakan kepada keduanya perkataan "ah" dan janganlah kamu membentak mereka dan ucapkanlah kepada mereka perkataan yang mulia”.

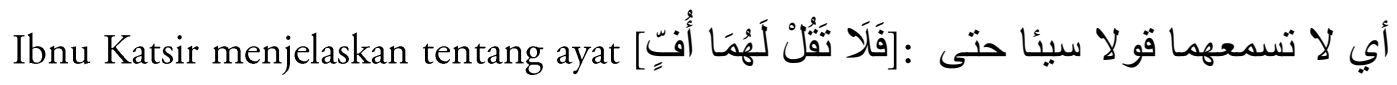
"Jangan memperdengarkan kepada orang tua, perkataan yang buruk. Bahkan sekedar ah yang ini merupakan tingkatan terendah dari perkataan yang buruk". ${ }^{16}$

Sikap selanjutnya adalah tawadhu' (rendah hati) kepada orang tua dan sikapilah mereka dengan penuh kasih sayang, sebagaimana dalam QS. Al-Isra' ayat 24:

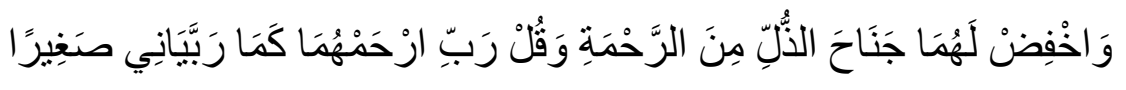

"Dan rendahkanlah dirimu terhadap mereka berdua dengan penuh kesayangan dan ucapkanlah: "Wahai Tuhanku, kasihilah mereka keduanya, sebagaimana mereka berdua telah mendidik aku waktu kecil”.

Sikap ihsan lain adalah tidak memandang orang tua dengan pandangan yang tajam, tidak bermuka masam atau wajah yang tidak menyenangkan, dan tidak meninggikan suara ketika berbicara dengan orang tua. Hal ini mengacu pada hadis Al Musawwir bin Makhramah mengenai bagaimana adab para Sahabat Nabi terhadap Nabi Shallallahu'alaihi Wasallam, disebutkan di dalamnya:

$$
\text { و إذا تكَلَّمَ خَفَضُو ا أصو اتَهم عندَه ، و ما يُحِدُّون إليه النظرَ؛ تعظيمًا لله }
$$

"Jika para sahabat berbicara dengan Rasulullah, mereka merendahkan suara mereka dan mereka tidak memandang tajam sebagai bentuk pengagungan terhadap Rasulullah". ${ }^{7}$

\footnotetext{
${ }^{16}$ Ibnu Kathir, Tafsir al-Quran al- 'Azhim, (Kairo: Dar al-Hadith, 1995).

${ }^{17}$ Al Bukhari, Shahih al-Bukhari, No. Hadis 2731.
} 
Bahkan Musthafa Al 'Adawi mengatakan bahwa setiap adab di atas terdapat dalil yang menunjukkan bahwa adab-adab tersebut merupakan sikap penghormatan. ${ }^{18}$

Sikap baik selanjutnya adalah tidak mendahului mereka dalam berkata-kata. Hal ini mengacu pada hadis dari Abdullah bin Umar radhiallahu'anhu beliau berkata:

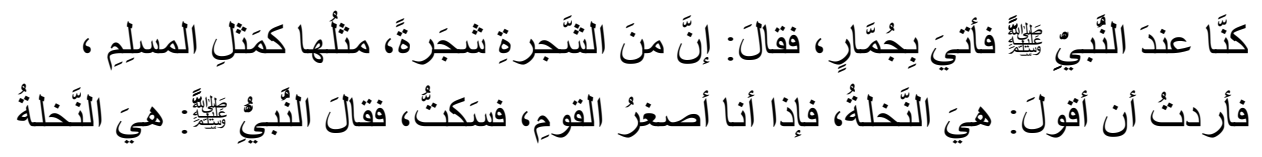

"Kami pernah bersama Nabi saw. di Jummar, kemudian Nabi bersabda: 'Ada sebuah pohon yang ia merupakan permisalan seorang Muslim'. Ibnu Umar berkata: 'sebetulnya aku ingin menjawab: pohon kurma. Namun karena ia yang paling muda di sini maka aku diam'. Lalu Nabi Shallallahu'alaihi Wasallam pun memberi tahu jawabannya (kepada orang-orang): "ia adalah pohon kurma”."19

Ibnu Umar melakukan demikian karena adanya para sahabat lain yang lebih tua usianya walau bukan orang tuanya. Maka tentu adab ini lebih layak lagi diterapkan kepada orang tua.

Mengutamakan orang tua daripada diri sendiri atau Ithaar dalam perkara duniawi juga termasuk bentuk sikap konkret berbuat baik kepada orang tua. Seorang diharapkan mengutamakan diri kita sendiri dari orang tua dalam perkara duniawi seperti makan, minum, dan perkara lainnya. Hal ini mengacu pada hadis Shahih tentang tiga orang yang bertawassul dengan amalan shalih yang salah satunya bertawassul dengan amalan baiknya kepada orang tua, diantara ia melakukan iitsaar kepada orang tuanya.

Sikap ihsan lain adalah mengajak orang tua kepada agama yang benar sebagai dalam QS. Maryam ayat 41-45.

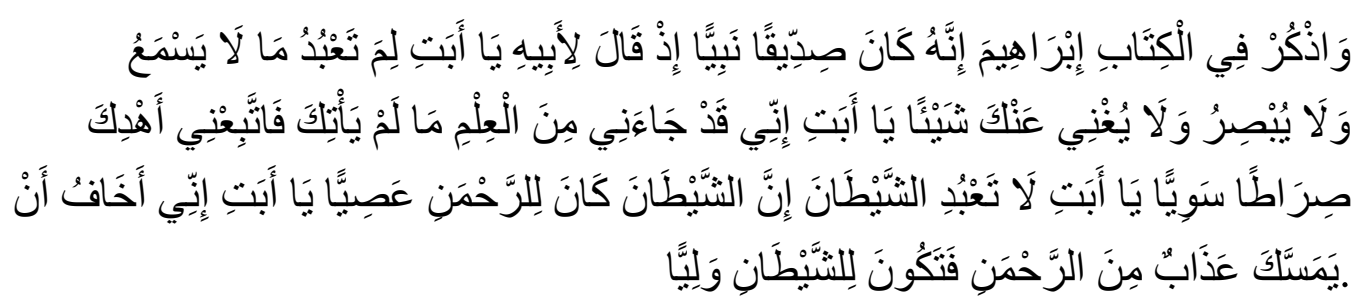

"Ceritakanlah (Hai Muhammad) kisah Ibrahim di dalam Al Kitab (Al Quran) ini. Sesungguhnya ia adalah seorang yang sangat membenarkan lagi seorang Nabi. Ingatlah ketika ia berkata kepada bapaknya; "Wahai bapakku, mengapa kamu menyembah sesuatu yang tidak mendengar, tidak melihat dan tidak dapat menolong kamu sedikitpun? Wahai bapakku, sesungguhnya telah datang kepadaku sebahagian ilmu pengetahuan yang tidak

\footnotetext{
${ }^{18}$ Musthafa Al 'Adawi, Tarbiyah al-Abna', (Kairo: Dar al-Hadith, 2009).

${ }^{19}$ Al Bukhari, Shahih al-Bukhari, No. Hadis 82. Muslim, Shahih al-Muslim, (Kairo: Dar al-Hadith 2007), No.
} Hadis 2811. 
datang kepadamu, maka ikutilah aku, niscaya aku akan menunjukkan kepadamu jalan yang lurus. Wahai bapakku, janganlah kamu menyembah syaitan. Sesungguhnya syaitan itu durhaka kepada Tuhan Yang Maha Pemurah. Wahai bapakku, sesungguhnya aku khawatir bahwa kamu akan ditimpa azab dari Tuhan Yang Maha Pemurah, maka kamu menjadi kawan bagi syaitan”.

Sikap selanjutnya adalah anak harus menjaga kehormatan orang tua sebagaimana hadis dari Abdullah bin Umar ra, Nabi saw. bersabda:

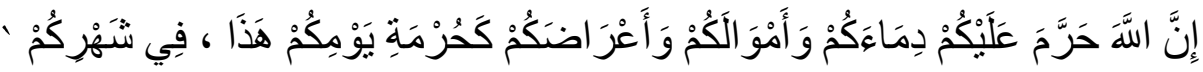

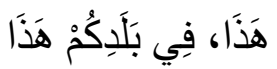

"sesungguhnya Allah telah mengharamkan atas sesama kalian darah kalian (untuk ditumpakan) dan harta kalian (untuk dirampais) dan kehormatan (untuk dirusak). Sebagaimana haramnya hari ini, haramnya bulan ini dan haramnya negeri ini”. ${ }^{20}$

Sikap lain adalah dengan memberi pelayanan-pelayanan kepada orang tua dan bantulah urusan-urusannya. Rasulullah saw. bersabda:

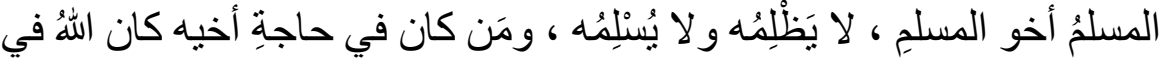

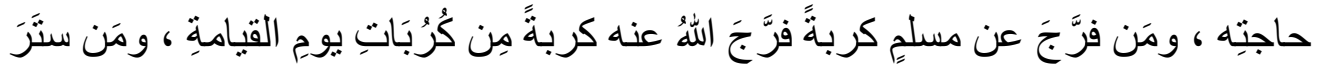

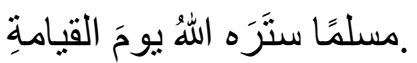

"Seorang Muslim adalah saudara bagi Muslim yang lain, tidak boleh menzhaliminya, tidak boleh membiarkannya dalam bahaya. barangsiapa yang memenuhi kebutuhan saudaranya sesama Muslim, maka Allah akan penuhi kebutuhannya. barangsiapa yang melepaskan saudaranya sesama Muslim dari satu kesulitan, maka Allah akan melepaskan ia dari satu kesulitan di hari kiamat. barangsiapa yang menutup aib seorang Muslim, Allah akan menutup aibnya di hari kiamat". ${ }^{21}$

Sikap kesembilan adalah menjawab panggilan mereka dengan segera, sebagaimana hadis dari Abu Hurairah ra., Nabi saw. bersabda:

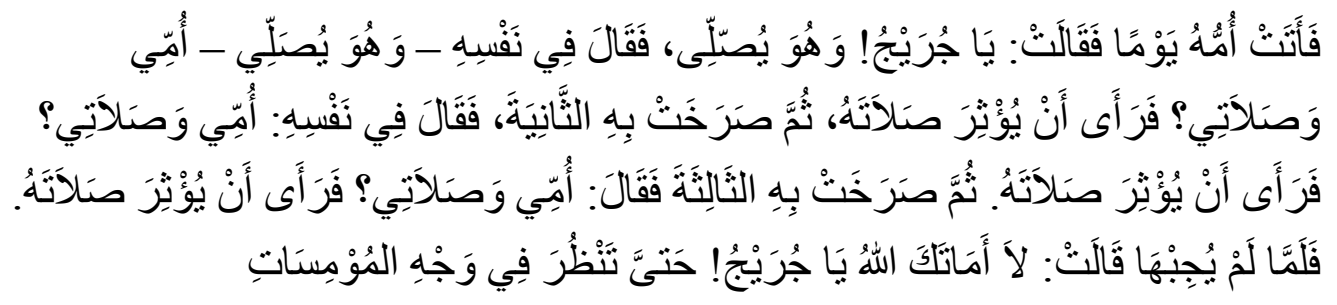

\footnotetext{
${ }^{20}$ Al-Bukhari, Shahih al-Bukhari.

${ }^{21}$ Al Bukhari, Shahih al-Bukhari, Hadis No. 2442.
} 
"Suatu hari datanglah ibu Juraij dan memanggil anaknya (Juraij) ketika ia sedang melaksanakan shalat, "Wahai Juraij." Juraij lalu bertanya dalam hatinya, "Apakah aku harus memenuhi panggilan ibuku atau meneruskan shalatku?" Rupanya dia mengutamakan shalatnya. Ibunya lalu memanggil untuk yang kedua kalinya. Juraij kembali bertanya di dalam hati, "Ibuku atau shalatku?" Rupanya dia mengutamakan shalatnya. Ibunya memanggil untuk kali ketiga. Juraij bertanya lagi dalam hatinya, "Ibuku atau shalatku?" Rupanya dia tetap mengutamakan shalatnya. Ketika sudah tidak menjawab panggilan, ibunya berkata, "Semoga Allah tidak mewafatkanmu, wahai Juraij sampai engkau melihat wajah pelacur". 22

Sikap lain adalah menghindari berdebat dengan mereka, jangan mudah menyalahnyalahkan mereka, jelaskan dengan penuh adab sebagaimana dialog Nabi Ibrahim as. dengan ayahnya. Sebagaimana juga diceritakan oleh 'Aisyah ra: "Kami keluar bersama Rasulullah saw. pada beberapa perjalanan beliau. Tatkala kami sampai di Al-Baidaa atau di daerah Dzatul Jaisy, kalungku terputus. Rasulullah saw. pun berhenti untuk mencari kalung tersebut. Orang-orang yang ikut bersama beliau pun ikut berhenti mencari kalung tersebut. Padahal mereka tatkala itu tidak dalam keadaan bersuci (dalam keadaan berwudu) dan tidak membawa air. Sehingga orang-orang pun berdatangan menemui Abu bakar AshShiddiq dan berkata, 'Tidakkah engkau lihat apa yang telah dilakukan oleh Aisyah? Ia membuat Rasulullah Shalallahu'alaihi Wasallam dan orang-orang berhenti padahal mereka tidak dalam keadaan bersuci dan tidak membawa air. Maka Abu Bakar pun menemuiku, lalu ia mengatakan apa yang dikatakannya. Lalu ia memukul pinggangku dengan tangannya. Tidak ada yang mencegahku untuk menghindar kecuali karena Rasulullah saw. yang sedang tidur di atas pahaku. Rasulullah saw. terus tertidur hingga subuh dalam keadaan tidak bersuci. Lalu Allah menurunkan ayat tentang tayammum. Usaid bin AlHudhair mengatakan, "Ini bukanlah awal keberkahan kalian wahai keluarga Abu Bakar". Lalu kami pun menyiapkan unta yang sedang aku tumpangi, ternyata kalung itu berada di bawahnya". 23

Sikap lain yaitu segera menyambut mereka ketika mereka masuk rumah, dan ciumlah tangan mereka. Hal ini mengacu pada hadis, dari Aisyah ra., ia berkata:

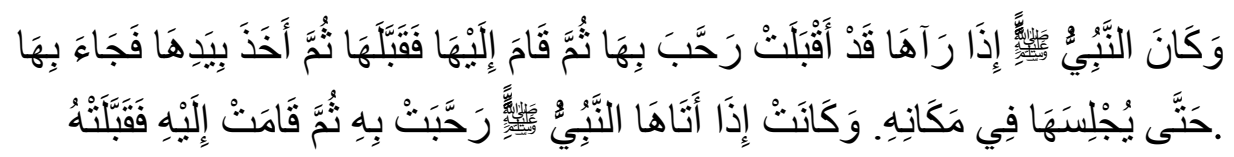

"Nabi Shallallahu 'alaihi wa sallam jika melihat putri Beliau Shallallahu 'alaihi wa sallam (Fathimah) datang ke rumah beliau, maka Nabi saw. menyambut kedatangannya. Beliau berdiri lalu berjalan menyambut, menciumnya, menggandeng tangannya lalu

\footnotetext{
${ }^{22} \mathrm{Al}$ Bukhari, Shahih al-Bukhari.

${ }^{23}$ Al-Nasai, Sunan al-Nasai, (Beirut: Dar al-Fikr, 2002), No. Hadis 309.
} 
mendudukkannya di tempat duduk beliau. Jika Nabi saw. mendatangi rumah Fathimah radhiyallahu anhuma, maka Fathimah menyambut kedatangan Nabi Shallallahu 'alaihi wa sallam. Dia bangkit dan berjalan kearah Beliau Shallallahu 'alaihi wa sallam lalu mencium (kening) Nabi saw.". 24

Sikap ihsan lainnya adalah tidak menganggu mereka di waktu mereka istirahat, sebagaimana firman Allah dalam surat An Nur ayat 58 (yang artinya): "Hai orang-orang yang beriman, hendaklah budak-budak (lelaki dan wanita) yang kamu miliki, dan orangorang yang belum baligh diantara kamu, meminta izin kepada kamu tiga kali (dalam satu hari), yaitu: sebelum shalat subuh, ketika kamu menanggalkan pakaian (luar)mu di tengah hari, dan sesudah sesudah shalat Isya'. (Itulah) tiga 'aurat bagi kamu. Tidak ada dosa atasmu dan tidak (pula) atas mereka selain dari (tiga waktu) itu. Mereka melayani kamu, sebahagian kamu (ada keperluan) kepada sebahagian (yang lain). Demikianlah Allah menjelaskan ayat-ayat bagi kamu. Dan Allah Maha Mengetahui lagi Maha Bijaksana”.

Tidak berbohong kepada orang tua juga termasuk sikap ihsan, karena Nabi saw. bersabda:

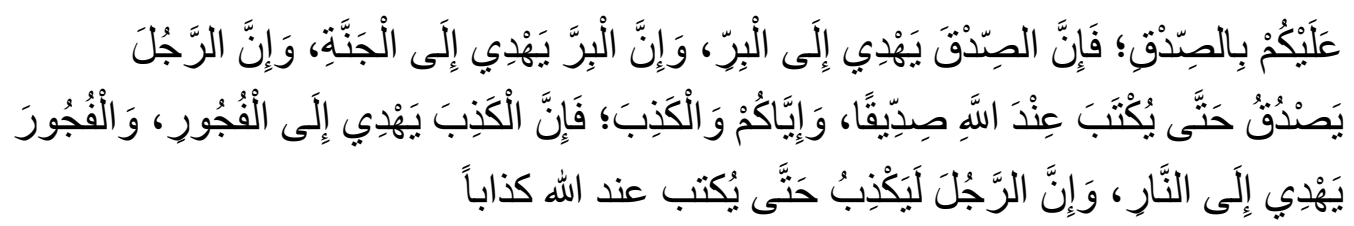

"Wajib bagi kalian untuk berlaku jujur. Karena kejujuran itu membawa kepada kebaikan dan kebaikan itu membawa ke surga. Seseorang yang senantiasa jujur, ia akan ditulis di sisi Allah sebagai Shiddiq (orang yang sangat jujur). Dan jauhilah dusta, karena dusta itu membawa kepada perbuatan fajir (maksiat) dan perbuatan fajir membawa ke neraka. Seseorang yang sering berdusta, akan di tulis di sisi Allah sebagai kadzab (orang yang sangat pendusta) ${ }^{25}$

Berbohong adalah perbuatan yang termasuk kategori dosa besar, lebih-lebih jika dilakukan kepada orang tua. Oleh karena itu salah satu bukti ihsan kepada mereka adalah selalu jujur kepada mereka. Tidak pelit untuk menafkahi mereka juga termasuk sikap ihsan. Hal ini mengacu pada hadis Nabi, Rasulullah saw. bersabda:

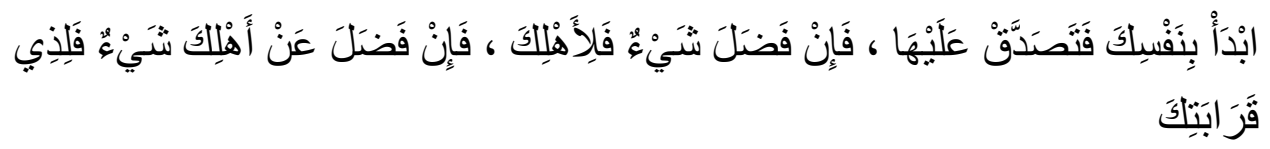

\footnotetext{
${ }^{24}$ Al Bukhari, Shahih al-Bukhari.

${ }^{25}$ Muslim, Shahih al-Muslim, Hadis No. 2607.
} 
"Mulailah dari dirimu sendiri, engkau beri nafkah dirimu sendiri. Jika ada lebih maka untuk keluargamu. Jika ada lebih maka untuk kerabatmu". ${ }^{26}$

Orang tua adalah orang yang paling berhak dinafkahi setelah diri sendiri dan keluarga. Muhammad bin Shalih Al Utsaimin menjelaskan bahwa seorang anak wajib menafkahi orang tuanya jika memenuhi dua syarat: (1) Orang tua dalam keadaan miskin, dan (2) Sang anak dalam keadaan mampu menafkahi. Jika dua kondisi ini tidak terpenuhi, maka tidak wajib. ${ }^{27}$

Akhlak baik lainnya adalah sering mengunjungi mereka, sebagaimana sabda Nabi saw.:

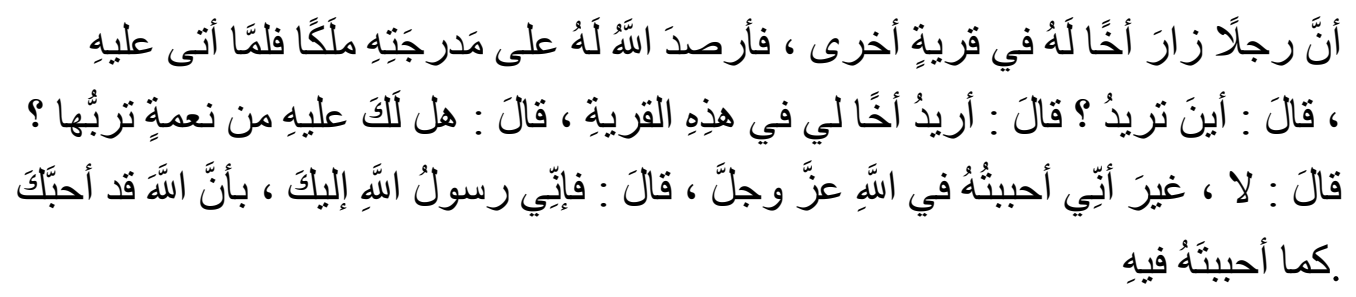

"Pernah ada seseorang pergi mengunjungi saudaranya di daerah yang lain. Lalu Allah pun mengutus Malaikat kepadanya di tengah perjalanannya. Ketika mendatanginya, Malaikat tersebut bertanya: “engkau mau kemana?”. Ia menjawab: “aku ingin mengunjungi saudaraku di daerah ini”. Malaikat bertanya: "apakah ada suatu keuntungan yang ingin engkau dapatkan darinya?". Orang tadi mengatakan: “tidak ada, kecuali karena aku mencintainya karena Allah. Maka malaikat mengatakan: "sesungguhnya aku diutus oleh Allah kepadamu untuk mengabarkan bahwa Allah mencintaimu sebagaimana engkau mencintai saudaramu karena-Nya“. ${ }^{28}$

Sebagaimana diketahui bahwa saling mengunjungi sesama Muslim saja sangat besar keutamaannya, apalagi yang dikunjungi adalah orang tua. Meminta dengan lemah lembut jika ingin meminta sesuatu kepada orang tua juga bentuk ihsan. Rasulullah saw. bersabda:

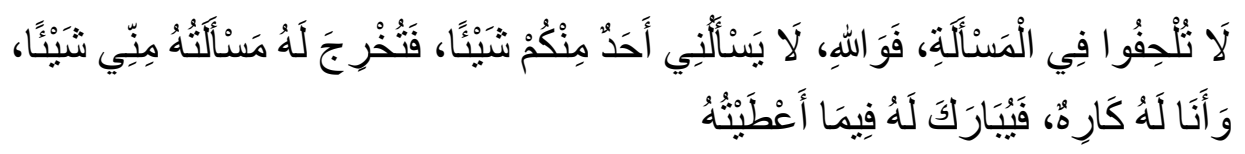

"Jangan kalian memaksa jika meminta. Demi Allah, jika seseorang meminta kepadaku sesuatu, kemudian aku mengabulkan permintaannya tersebut dengan perasaan tidak senang, maka tidak ada keberkahan pada dirinya dan apa yang ia minta itu" ${ }^{29}$

\footnotetext{
${ }^{26}$ Muslim, Shahih al-Muslim, Hadis No. 997.

${ }^{27}$ Muhammad bin Shalih Al Utsaimin, Makarim Akhlak, (Riyadh: Muassasah al Khoiriyyah, 1428).

${ }^{28}$ Muslim, Shahih al-Muslim, Hadis No. 2567.

${ }^{29}$ Muslim, Shahih al-Muslim, Hadis No 1038.
} 
Meminta kepada orang lain dengan memaksa adalah akhlak yang buruk, apalagi jika yang dimintai adalah orang tua. Sikap memaksakan kehendak padahal orang tua sedang kurang itu termasuk akhlak yang buruk.

Jika orang tua dan istri bertikai maka sebagai anak harus berlaku adil kepada orang tua. Sebagaimana Allah berfirman dalam QS. Al-Maidah ayat 8.

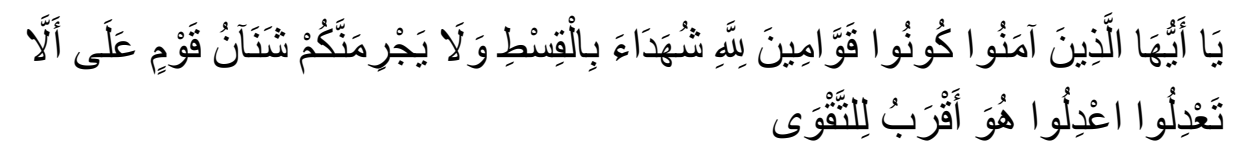

"Hai orang-orang yang beriman hendaklah kamu jadi orang-orang yang selalu menegakkan (kebenaran) karena Allah, menjadi saksi dengan adil. Dan janganlah sekalikali kebencianmu terhadap sesuatu kaum, mendorong kamu untuk berlaku tidak adil. Berlaku adillah, karena adil itu lebih dekat kepada takwa. Dan bertakwalah kepada Allah, sesungguhnya Allah Maha Mengetahui apa yang kamu kerjakan”.

Melakukan musyawarah dengan orang tua dalam urusan tertentu juga termasukan sikap ihsan kepada mereka, termasuk mengajak mereka diskusi terkait hal tertentu.

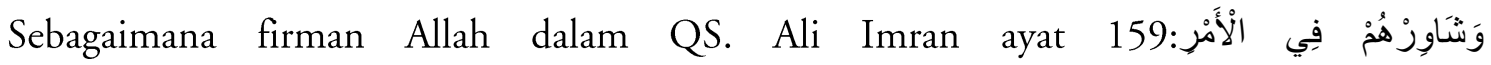
"Bermusyawarahlah dengan mereka dalam urusan-urusanmu".

Sikap ihsan yang cukup tinggi lainnya adalah menziarahi kubur mereka dan seringsering doakan mereka., sebagaimana sabda Nabi saw.:

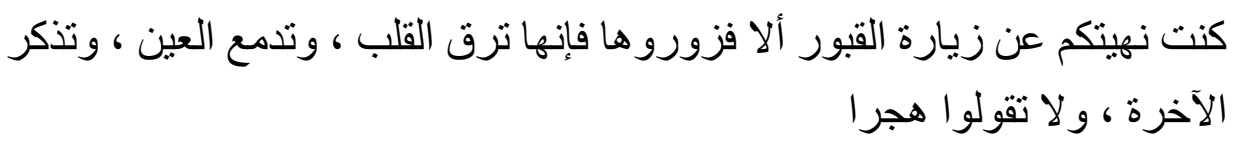

"Dulu aku pernah melarang kalian untuk berziarah-kubur. Namun sekarang ketahuilah, hendaknya kalian berziarah kubur. Karena ia dapat melembutkan hati, membuat air mata berlinang, dan mengingatkan kalian akan akhirat namun jangan kalian mengatakan perkataan yang tidak layak (qaulul hujr), ketika berziarah". ${ }^{30}$

Sikap-sikap di atas merupakan ejawantah dan bukti seseorang berbuat baik (ihsan) kepada kedua orang tua. Besikap ihsan kepada orang tua harus dibuktikan dalam kehidupan sosial dalam hubungan antara anak dan orang tua bahkan dengan masyarakat secara luas.

\footnotetext{
${ }^{30}$ Al-Hakim, al-Mustadrak, (Beirut: Dar al Fikr, 1997), Hadis No..1393.
} 


\section{PENUTUP}

Dari hasil dan pembahasan yang ada, dapat disimpulkan bahwa bersikap ihsan kepada orang tua hukumnya wajib sebagaimana Allah telah menganjurkan secara tegas dan jelas dalam Al-Quran, tidak hanya disebut satu kali tapi berkali-kali sebanyak 13 kali dan 7 kali disandingkan dengan seruan Tauhid. Berlaku Ihsan kepada kedua orang tua dalam AlQuran adalah berupa tauhid yang harus dikedapankan yang mengiringi kebaktian terhadap kedua orang tua. Ihsan bersifat mutlak meliputi semua kebaikan termasuk kategori apakah status agama kedua orang tua muslim ataupun kafir. bersikap beradab ketika kedua orang tua dalam masa lemah, renta dan tua yang sangat membutuhkan perlindungan dan kasih sayang dari anaknya. Bersuara lembut dan hormat ketika berkomunikasi dengannya. Bersikap tawadhu' dan mendoakan mereka ketika masih hidup maupun telah tiada. Selalu memohon kepada Allah untuk di anugerahi jalan mudah untuk berkhidmat kepada kedua orang tua.

\section{DAFTAR PUSTAKA}

Al-Quran al-Karim

Abdullah Irwan. 2006. Sangkan Paran Gender. Yogyakarta: Pustaka Belajar.

Al 'Adawi, Musthafa. 2009. Tarbiyah al-Abna'. Kairo: Dar al-Hadith.

Al Utsaimin, Muhammad bin Shalih. 1428. Makarim Akhlak. Riyadh: Muassasah al Khoiriyyah.

Al-Bukhari. 2000. Shahih al-Bukhari. Beirut: Dar al-Fikr.

Al-Hakim. 1997. al-Mustadrak. Beirut: Dar al Fikr.

Al-Nasai. 2002. Sunan al-Nasai. Beirut: Dar al-Fikr.

Angga Hermawan, Adliyah Adliyah, M Imam Pamungkas. 2017. "Akhlak Anak terhadap Orang Tua Berdasarkan Al-Qur'an (Analisis Pendidikan terhadap QS. An-nissa: 36, QS. Al-Israa': 23-24, QS. Al-Ankabuut: 8 dan QS. Al-Ahqaaf: 15). Proceeding Pendidikan Agama Islam, Vol 3, No 2, Agustus.

Bertens. 2000. Etika. Jakarta: Gramedia Pustaka Utama.

Depdikbud. 2003. Kamus Besar Bahasa Indonesia. Jakarta: Balai Pustaka.

Ibnu Fariz. 2008. Maqayis al-Lughah. Kairo: Dar al-Hadith.

Ibnu Kathir. 1995. Tafsir al-Quran al-'Azhim. Kairo: Dar al-Hadith.

Ibnu Manzhur. 1995. Lisan al-Arab. Kairo: Dar al-Hadith.

Jazuli, Fatkhul Mannan. 2015. "Konsep Pendidikan Akhlak Anak terhadap Orang Tua Dalam Al-Qur'an Surat Al Isra 23-25”. IAIN Salatiga.

Karim, Abdul. 2015. "Reformulasi Tafsir Ijtima’i dalam Menjawab Problematika Sosial". Hermeneutik: Vol. 9, No.2. 
Majma' al-Lughah al-'Arabiyyah, al-Mu'jam al-Wasith. 1999. Kairo: Maktabah al-Syuruq al-Dualiyyah.

Misbah, Muhammad Taqi. 1376. Falsafehye Akhlaq. Tehran: Ettela'at.

Muslim. 2007. Shahih al-Muslim. Kairo: Dar al-Hadith.

Syirazi, Makarim. 1385. Tafsir al-Amthal fi Tafsir Kitabillah al-Munzal. Tehran: Dar alKutub al-Islamiyah. 